\title{
Cash Flow or Present Value: What's Lurking Behind That Hedge?
}

\author{
Michael T. Belongia and G. J. Santoni
}

\begin{abstract}
O moderate swings in their earnings induced by unexpected changes in interest rates. Among other things. financial institutions are increasing the percentage of their portfolios devoted to short-term consumer loans and are making greater use of adjustable rate mortgages, floating rate loans and interest rate swaps. In addition, a growing number of these firms are using financial futures to reduce their exposure to interest rate risk.'
\end{abstract}

Financial futures are relatively new. As with any new tool, leaming how to use it has been a costly experience. Most troublesone has been the realization that seemingly well-designed hedges have left the firm exposed to interest rate risk. In some cases, at least, firms have experienced this problem because they have tried to hedge their net cash flow:

The purpose of this paper is to show that any hedge designed to maintain the net cash flow of a portfolio in

Michael T. Belongia and G. U. Santoni are senior economists at the Federal Reserve Bank of St. Louis. Thomas A. Pollmann provided research assistance.

'See Booth, Smith and Stolz (1984). In addition, the Federat Home Loan Bank Board has recently adopted a set of regulations designed to deal with the problem of interest rate risk. See Federal Home Loan Bank Board (1984).

2See Zaslow (1984).

Hedging strategies designed to minimize the variance of net cash flow (net interest margin) are discussed in Hill, Liro and Schneeweis (1983); Jacobs (1982); Koch, Steinhauser and Whigham (1982); Parker and Daigler (1981): Pitts and Kopprasch (1984); Toevs (1983); Asay, Gonzalez and Wolkowitz (1981); and Drabenstott and McDoniey (1984). the face of unexpected interest rate changes necessar" ily does so at the expense of allowing the market value of the portfolio to vary with interest rates. Since any relationship between the portfolio's market value and interest rates is typically what is meant by interest rate risk, these hedges are ineffective in insulating the value of the portfolio against this risk. ${ }^{3}$

On the other hand, hedging to maintain the market value (rather than net cash flow) of the portfolio neces. sarily results in a stream of cash that changes as the interest rate changes. Some simple hedging examples are constructed in this paper to show that different methods of hedging can produce equivalent results in terms of the maintenance of the portfolio's market value even though the net streams of cash in terms of both total amount and timing) differ across the various methods.

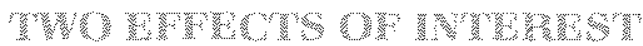

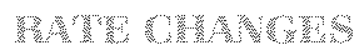

Unexpected interest rate changes have two important effects on the ypical financial portfolio. First a change in the interest rate means that the present

${ }^{4}$ See Samueison (1944), p. 19. His footnote 1 is particulaty instructive on this point. Another important problem that the hedger must contront is basis risk. This is the risk that the spread between the prices of the futures and cash instrument may change during the period of the hedge. See Cicchetti, Dale and Vignola (1981), Ederingion (1979), Franckle (1980), Franckle and Senchack (1982) and Koppenhaver (1984). A special case of basis risk, one that is particularly relevant in hedging financial porttolios, is the possibility that the slope of the yield curve may change during the period of the hedge. Having warned the reader, we ignore the problem of basis risk in the following discussion. 
(market) value of any given stream of cash has changed. For example, a rise in the interest rate is equivalent to a fall in the present value of the given cash stream. Second, a given change in the interest rate will not result in proportional changes in the present values of different cash streams. Roughly, the more distant the net cast receipts are from the present that is, the greater the stream's duration, the larger the percentage change in the present value of the stream for a given change in the inferest rate. "This can be summarized by stating that different assets, liabilities or portfolios generally have different interest rate elasticities.

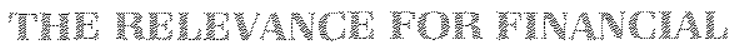

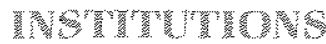

Financial institutions, particularly savings and loan associations, maintain portfolios that are very sensitive to interest rate changes. This sensitivity arises because savings and loan association portfolios are composed of financial assets whose lives (dumtions) are long relative to the lives of their liabilities. In short, the market value of assets contained in the portfolio are more interest ${ }^{-e l a s t i c ~ t h a n ~ l i a b i l i t i e s . ~ A s ~ a ~ r e s u l t, ~}$ increases in the interest rate are accompanied by langer percentage reductions in the present value of assets than in the present value of liabilities. On bal ance, these changes cause the net present value of the portfolio to shrink. The reverse occurs when interest rates fall. The different interest elasticities of assets and liabilities give the net present value of the portfolio an accordion-like quality with the interest rate call ing the tune.

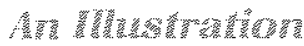

Table 1 illustrates the effect that a change in the interest rate can have on the net present value land

\footnotetext{
'Since this paper is concemed with changes in interest rates that leave the term structure unaltered, "the" interest rate is used as a shorthand method of referring to the whole complex of interest rates.

6For discussions of duration, see Kaufman (1984); Bierwag, Kauf. man and Toevs (1983); Toevs (1983); Santoni (1984); Samuelson (1944); Hicks (1939), pp. 184-88; and Alchian and Allen (1977), pp. $143-68$.

Interest elasticity is the ratio of the percentage change in the present value of an asset, liability or portiolio to the percentage change in the interest rate. In the case of single assets or liabilities, interest rate elasticity is always negative, indicating that present value is inversely related to the interest rate. However, for a portfolio containing both assets and liabilities, interest rate elasticity may be positive, negative or zero. See Samuelson (1944).

${ }^{8}$ See Santoni (1984).
}

owner's wealth of a portfolio composed of relatively long-lived assets and short-lived liabilities. For simplicity's sake, the life of the portfolio (firm/ is assumed to be one vear. The firm has extended a loan with a face value of $\$ 1,000$ to be paid at the end of the vear at an interest rate of 10 percent. The present value of the loan and, thus, the amount paid to the borrower is $\$ 909.09$. To fund the loan, the firm borrows $\$ 909.09$ for 90 days at 8 percent interest. The spread net interest margin between the lending and borrowing rates is the retum the firm earns for employing its specialized capital in intermediating between borrowers and lenders:"

The firm's liability must be rolled over every 90 days if it plans to hold the asset to maturity. The amount the firm will owe in 90 days is $\$ 926.75 \quad=\$ 909.09$ (1.08) ${ }^{* 2}$. The firm plans to refinance this amount by borrowing for another 90 days." Since the proceeds from the new liability are used to pay the old liability, the firm's net receipts at this time are zero. The firm expects to roll over its borrowings every 90 days at the same rate of interest. At the end of the year, the firm anticipates having to pay $\$ 981.821=909.09 \times 1.081$, which will be paid out of the $\$ 1,000$ proceeds it receives from its matured asset. 'The firm's expected net receipt at yearend is $\$ 18.18$. At a maket rate of interest of 10 percent, the present value of this amount is $\$ 16.53 i=\$ 18.18 / 1.10$. Panel $A$ of table 1 shows the streams of expected receipts and payments that gen erate this increase in the firm's net present value.

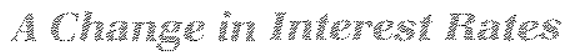

Panel $B$ of table 1 illustrates the effects on the planned streams of receipts and payments of an unexpected 50 basis-point increase in all interest rates that occurs immediately after the initial loan and borrow ing contracts are signed. Since the interest rate on the loan the firm has made does not change, this receipt remains fixed. However, the firm's refunding costs are higher at the liability refundings that occur on days 90 , 180 and 270 , so that at the end of the year the firm expects to pay $\$ 985.22$ out of the proceeds of its loan. Its net receipts at year-end fall to $\$ 14.78$, while the present value of its net receipts the market value of the firm's equityl declines to $\$ 13.38$.

\footnotetext{
In particular, we assume that the spread does not arise because the firm is laking advantage of an upward-sloping yield curve. Rather, the above examples assume that the yieid curve is flat

10For a discussion of present and future values, see Alchian and Alten $(1977)$, pp. $143-68$.
} 


\section{Table 1}

\section{Changes in Present Value and Interest Rate Elasticity}

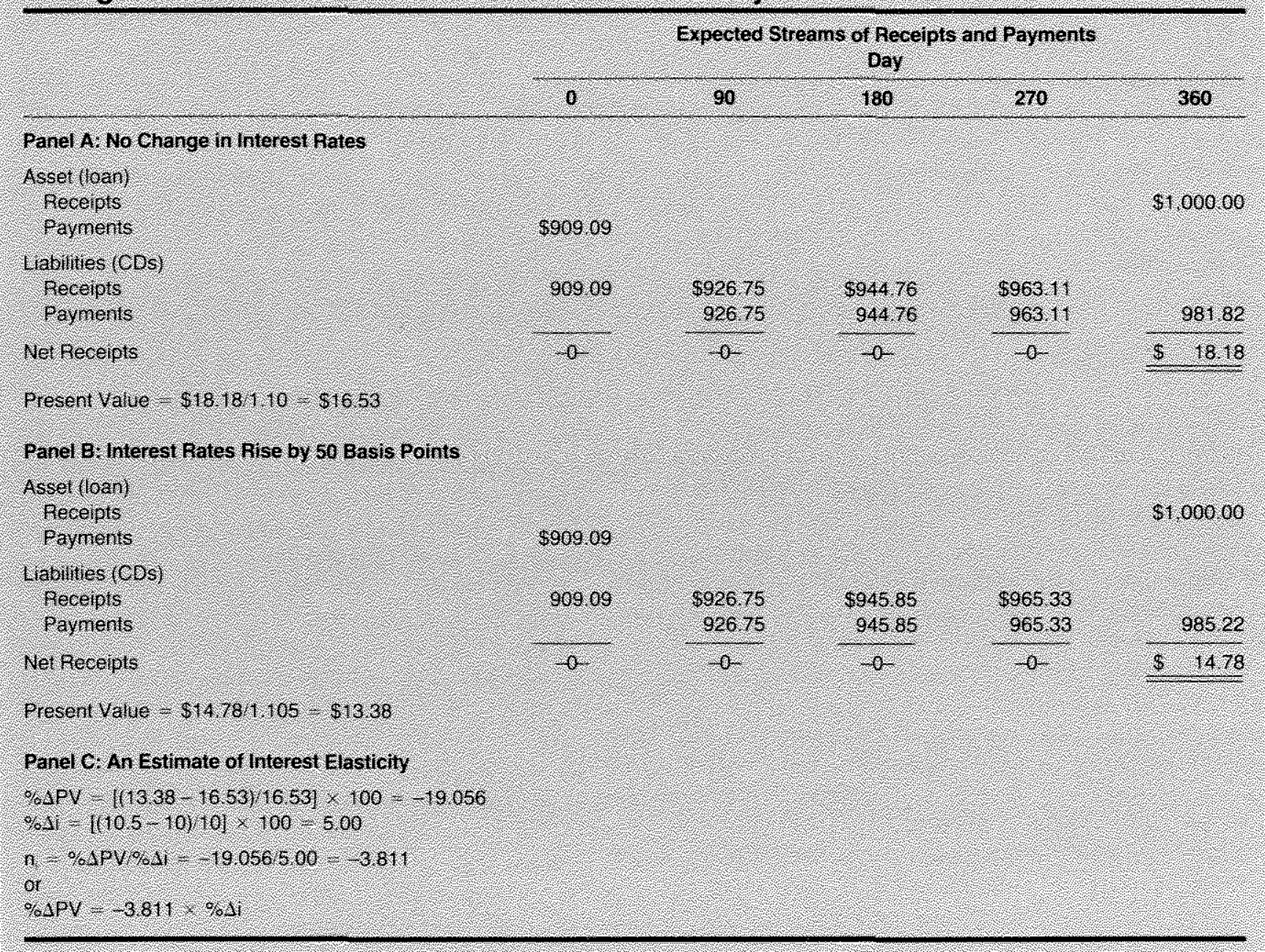

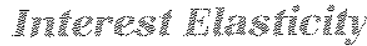

The ratio of the percentage change in the portfolio's present value to the percentage change in the interest rate is the interest rate elasticity of the portfolio $\left(n_{\mathrm{i}}\right)$. This ratio is estimated in panel $C$ of table 1. "Interest elasticity is negative in this example, indicating that the present value of the portfolio is related inversely to the interest rate. Furthermore, the absolute value of the elasticity is about 3.8 , indicating that the percentage change in the present value of the firm's portfolio is about 3.8 times larger than the percentage change in

"Interest elasticity is "estimated" in panel $C$ because, strictly speaking, interest elasticity accurately measures the relationship between net present value and the interest rate only for small changes in the interest rate. See Hicks (1939), pp. 184-88. the interest rate. The present value of this portfolio is very sensitive to interest rate changes."

Interest rate elasticity is essentially a measure of the interest rate risk to which the firm is exposed. The larger the absolute value of interest rate elasticity, the greater the firm's exposure. A manager who wishes to minimize this exposure must apply a hedge that, in the limit, reduces the interest elasticity of the portfolio to zero

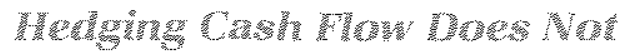

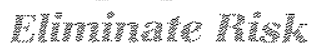

As mentioned above, a prevalent hedging objective

12Santoni (1984) estimates the elasticity to be about -2.5 for savings and loan associations and about -1.0 for banks. 
has been to hedge the nel cash flow (net interest margin of the portfolio, It is relatively simple to show that pursuing this objective, even if successful, does not eliminate the firm's exposure to interest rate risk.

Consider the example in panel $B$ of table 1 . Interest rates have risen by 50 basis points, and the net receipt at year-end has declined to $\$ 14.78$ from its anticipated level of $\$ 18.18$. Suppose, however, the fim had hedged so as to "lock in" each period's refunding cost at 8 percent and thereby protect is year-end receipts from interest rate changes. As a result, the firm receives $\$ 18.18$ at year-end even though interest rates have increased. While the firm's net cash flow 2 percent on the loan of $\$ 909.09-\$ 18.18$ ) is the same as if no change in interest rates had occurred, the present value of the portfolio (its market value and owner's wealth/ falls from $\$ 16.53$ to $\$ 16.45$.

This reduction in present value is considemably smaller than the reduction that would occur if the firm took no action to protect its net cash flow. It is clear, however, that this method of hedging leaves the firm exposed to interest rate risk, and the larger the unexpected change in the interest rate, the greater is the change in the present value of the portolio and the wealth of firm owners."

Furthermote, this example assumes that the planned life of the firm is only one year. The planned lives of most "real world" firms are much longer so that, in the limit, the percentage change in the present value of the porfolio for a firm that perfectly hedges its net cash flow will be equal in absolute value to the percentage change in the interest rate. "For example, if the interest rate should rise from, say, 8 percent 109 percent, the present value of the portolio falls by 12.5 percent. Firms that adopt hedging strategies with the objective of locking in net interest margin leave themselves exposed to considerable interest rate risk.

\footnotetext{
${ }^{13}$ At this point we are not concerned with exactly how this is accomplished. Particular methods of hedging are discussed below.

${ }^{17} \mathrm{~A}$ number of factors influence the magnitude of the percentage change including net interest margin and the interest elasticities of assets and liabilities. See Belongia and Santoni (1984b).

${ }_{15}$ Let $P$ represent present value and $C$ be a perpetual and constant net stream of cash. If $r$ is the interest rate, the present value of the cash stream is:

$$
\begin{aligned}
& \mathrm{P}=\frac{\mathrm{C}}{\mathrm{r}} \text { and } \\
& \frac{\mathrm{dP}}{\mathrm{dr}} \frac{\mathrm{r}}{\mathrm{P}}=-\frac{\mathrm{C}}{\mathrm{r}^{2}} \frac{\mathrm{r}}{\mathrm{P}}=-1 .
\end{aligned}
$$
}

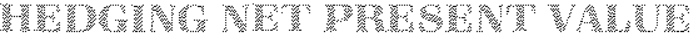

The table 1 example can be extended to show how hedging in the financial futures market can be used to protect the net present value of the frm. "The following example will illustrate that, as interest rates change, the net sheam of cash must diverge from the stream initialy planned in terms of its total amount, its timing or both, if the net present value of the portolio is to remain unchanged.

There also appeans to be some confusion concerning whether a "slack" or a "strip" of financial furures is more effective as a hedging technique. A stack is the sate or purchase of a series of futures will the same delivery date. A strip, on the other hand is the sale or purchase of a series of futures with different delivery dates. The following examples show that in principle, both stacks and strips can be used offectively to hedge the portolio's present value even though each generates a different cash stream for a given change in the interest rate.

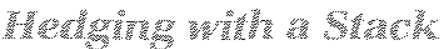

The example shown in panel $A$ of table 2 is the same as the pane $\mathrm{A}$, table 1 example except that it assumes the firm has sold a stack of 13 -week Treasury bill futumes contracts that will mature in 90 days at a 10 percent discount." Ninety days from now the firm must deliver Treasury bills with a face value of $\$ 2,918.67$ not shown in table 2 and a remaining maturity of 13 weeks. The method used to calculate values for the various hedges is described in the appendix. Since the discount rate specined in the contract is 10 percent, the firm will receive a payment of $\$ 2.84994$ $i=\$ 2,918.67 / 1.10)^{2-5}$ when in delivers the Treasury bills. The frm must acquire these bils in order to make delivery, and the expected purche price, given the curcent structure of interest rates, is $\$ 2,849,94^{\prime \prime}$. If intterest rates remain unchanged, expected and actual costs will be the same so that the actaral receipts and payments generated by the furures contract will net out. The fim's net flow of receipts is zero until year

\footnotetext{
16 For ease of exposition, the following example assumes that the costs of transacting in the futures market is zero. While these costs are relatively low, they are not trivial. See Kane (1980).

The assumption that the yield curve is flat and that there is no borrower-specific risk means that the discount rate on 90-day govemment securities will be the same as the discount rate the firm obtains on its ore-year loan.

in fact, most futures contracts are setiled by stmply reversing the original transaction so that a firm that is shor Treasury bill futures may not actually acquire the Treasury bills to settle its contract.
} 
Table 2

Hedging with a Stack

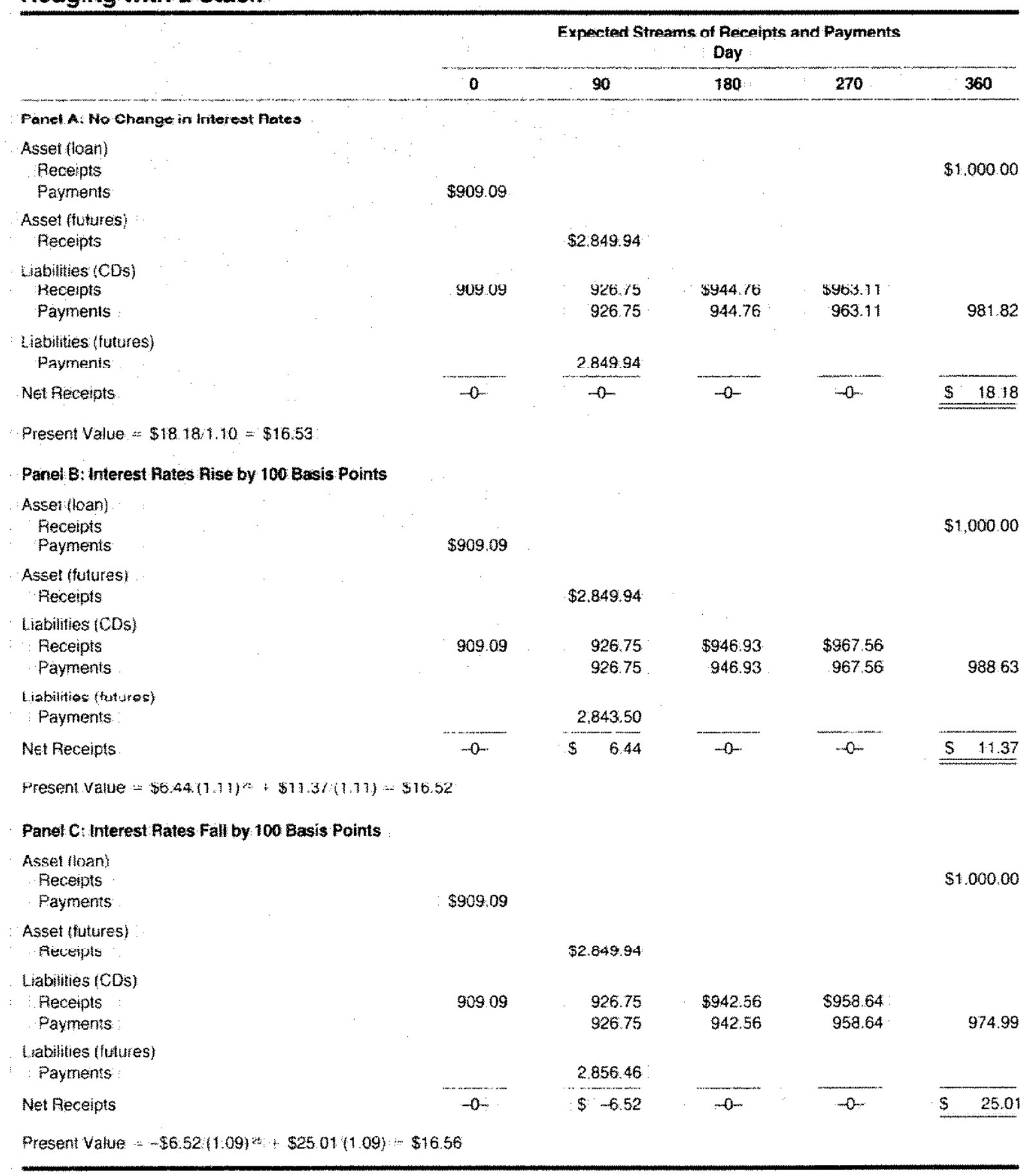


end when it receives $\$ 18.18$. The present value of this amount at the 10 percent market interest rate is $\$ 16.53 .^{13}$

In panel B of table 2, all interest rates are assumed to rise unexpectedly by 100 basis points immediately atter the loan and funding contracts are signed. As a result, the firm's refunding costs rise so that the expected net receipt at year-end falls to \$11.37. Notice, however, that the increase in the interest rate reduces the expected cost of acquiring the Treasury bills to $\left.\$ 2,843.50 t=\$ 2,918.6 \% /(1.11)^{2}\right)$. Since the price the firm will receive for the delivery of the Treasuy bils is fixed by the contract at $\$ 2,849.94$, the futures contract will generate an expected net receipt of $\$ 6.44$ upon delivery 90 days from now. The present value of this amount plus the present value of the expected yearend receipt is $\$ 16.52$ and is very close to the portfolio's present value for the case in which interest rates re main unchanged."

Panel $C$ of table 2 shows the effect of a 100 basispoint decline in all interest rates. This lowers refunding costs and waises the expected net receipt at yearend to $\$ 25.01$. It also maises the expected cost of acquiring the Treasury bills to $\$ 2,856.461=\$ 2,918.6 \%$ $(1.09)^{2.1}$, resulting in a net cash outflow of $\$ 6.52$ in 90 days. The present value of the year's expected cash stream is $\$ 16.56$, which agan is almost the same as the case in which interest rates remained unchanged.

Notice that the expected net cash flows experienced by the firm in panels $B$ and $C$ are considerably different in both timing and amount from the cash stream in panel $A$. Yet, the present value of the portfolio is virtually identical in all three cases. Clearly, protecting net cash flow is not necessary to protect the portfolio's net present value. Kather, as shown above, hedges that hold net cast flow constant ensure that the portfolio's present value will vary with interest rates.

\footnotetext{
${ }^{19}$ For a more detailed discussion of the types of financial futures available, discounting methods, terms of the contracts, etc., see Stigum (1981), pp. 151-70. Belongia and Santoni (1984a) discuss some basic principles of hedging with financial futures as well as some of the problems of employing them to hedge financial portiolios.

20Large changes in the interest rate will have some noticeable effect on the present value of the portfolio. The interest rate elasticity of the portfolio enters the calculation of the risk-minimizing hedge. Strictly speaking, this elasticity is an accurate measurement of the relationship between the interest rate and the portolio's present value only for small changes in the interest rate. The change in the interest rate is 10 percent in the panel $B$, table 2 example. This relatively large change in the interest rate is the reason that the portfolio's present value does not remain constant.
}

Had interest rates changed by more than 100 basis points, the vear-end receipts indicated in panels $B$ and $C$ of table 2 would have been smaller if interest rates had increased and larger if interest rates had fallen. The gains or losses generated by the futures contract, however, would have been larger as well, with the result that the present value of the portlolio would be little affected by the change in interest rates. of course, interest rates might vary ematically during the hedging period, rising one day and falling the next. However, the resulting changes that occur in the expected stream of net receipts induced by the changes in the interest rate will be sufficient 10 hold the present value of the portfolio very close to its original level.

Two cautions are important when interpreting this example. First, the analysis above is static. It considers the present value of the portfolio at a single point in time. As the firm moves through time, the hedge must be monitored because the size of the hedge depends upon the interest elasticity of the potfolio, which will change, along with the present value of the portolio, as the assets and liabilities age. It also is important to note that, when the stack is settled on day 90 , the firm must sell new contracts to protect itself in the subsequent period.

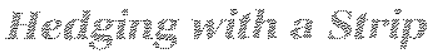

The example presented in table 3 considers the same set of conditions as those presented previously except that the firm chooses to hedge its portfolio with a strip of 13-week Treasury bill futures contracts at a discount of 10 percent. One contract is dated for delivery in 90 days, one in 180 days and one in 270 days. Each contract has a face value of $\$ 997.27$ isee the appendix for the method of computing this amount. Since the contracted rate of discount is 10 percent, the firn will receive $\$ 973.79 \quad=\$ 997.27 / 1.10)^{25}$ on each delivery date. Currently, this amount also is the expected cost of covering the contract.

Panel $A$ lists the firm's receipts and payments, asm suming no change in the interest rate. Again, payments and receipts cancel until year-end when the net receipt is $\$ 18.18$ present value of $\$ 16.53$ ?

Panel $B$ shows the effect on the streams of receipts and payments of an unexpected 100 basis-point increase in all interest rates. The firm's refunding costs rise, causing the net year end receipt to fall to $\$ 11.37$. The expected cost of covering each of the futures contracts, however, falls to $\$ 971.59(=\$ 997.27 / 1.11)^{: 5 i}$, rem sulting in a net cash receipt of $\$ 2.20$ at the end of 90 , 
Table 3

\section{Hedging with a Strip}

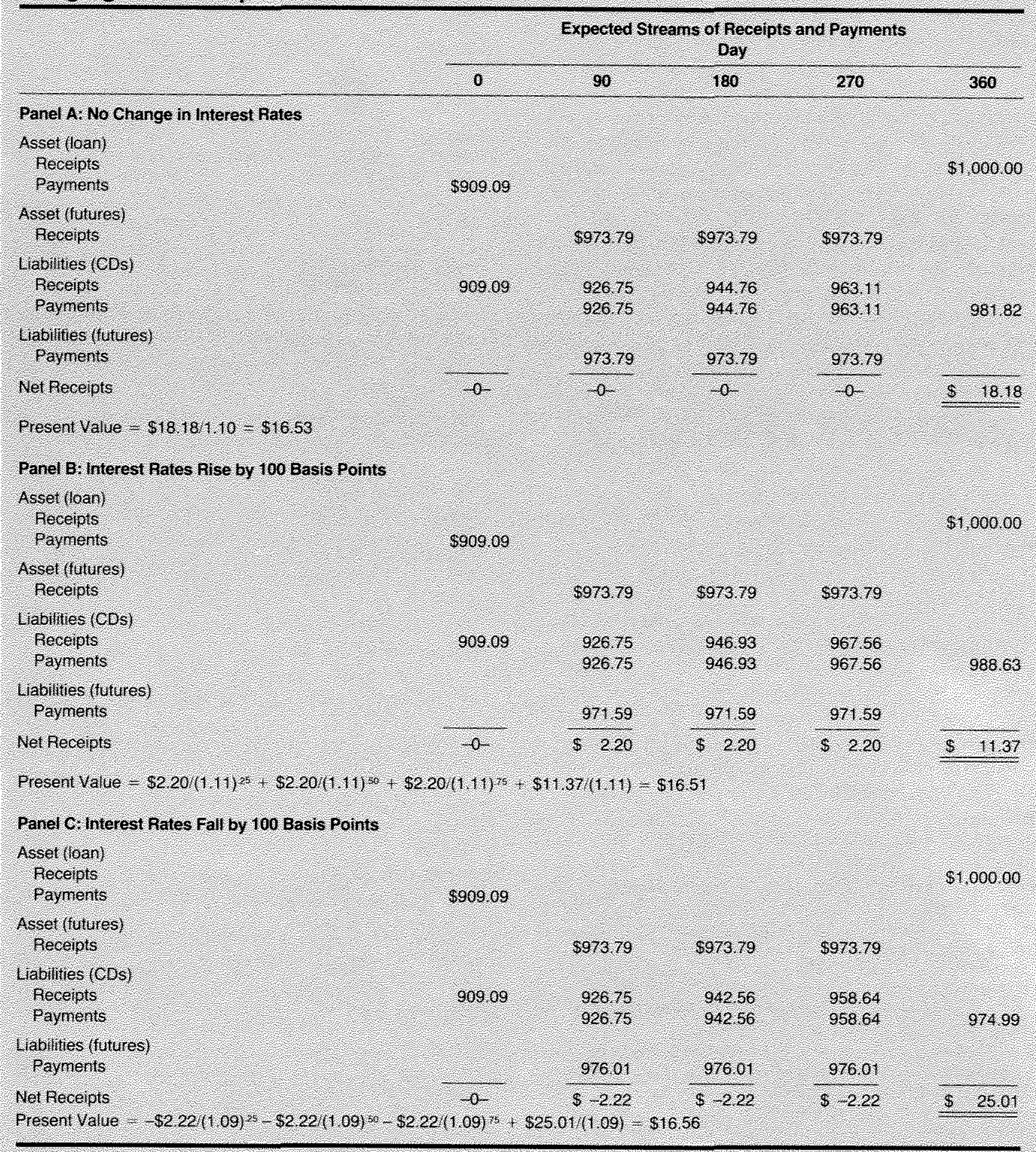


180 and 270 days. The present value of this stream of cash added to the present value of the year-end receipt is $\$ 16.51$.

Panel $C$ shows the effect of a 100 basis-point decline in interest rates. While the net stream of cash is different in both timing and amount, the net present value of the portfolio remains very neal its original value.

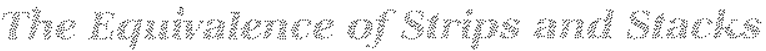

The above examples llinstrate that strips and stacks, if constructed properly, are equivalent in terms of protecting the net present value of the portfolio fand weal th of the firm's owners in the face of interest ate changes. However, the two methods result in different net cash flows both in timing and amount, and this may lead management to prefer one method to the other. Furthermore, we have ignored the transaction and administmative costs associated with hedging, which mav be different for strips vs. stacks. Other things the same, the firm will prefer the method that minimizes these costs.

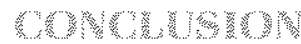

The financial literature contains many examples of hedging strategies designed to protect the fim's net cash flow or net interest margin. This, of course, may be a management objective. Any hedge that maintains net cash flow as interest rates change, however; does so at the expense of subjecting the present value of the portfolio and the wealth of firm owners to interest rate risk.

In contrast hedges that protect the present value of the portfolio necessarty imply net cash flows that vary with interest rates. There are various reasons why particular cash flows may be important to the management of the firm. If, however, these concerns permit some degree of substiution between the lotal volume of the flow, its timing or both, they do not necessavily conflict with the objective of hedging the present value of the portfolio.

\section{Whror was}

Alchian, Armen, and William R. Allen. Exchange and Production. Competition, Coordination, and Control, 2nd ed. (Wadsworth, 1977), pp. $143-68$.

Asay, Michael R., Gisela A. Gonzalez, and Benjamin Wolkowitz. "Financial Futures, Bank Portiolio Risk and Accounting," Journal of Futures Markets (Winter 1981), pp. $607-18$.

Belongia, Michaeł T., and G. J. Santoni. "Hedging Interest Rate Risk with Financial Futures: Some Basic Principles," this Review (October 1984a). pp. 15-25.
-Derivation of the Set of Exact Hedges for the Finarof St. Lous (October 1984b)

Bierwag. G. O., George G. Kaufman and Alden Toevs. "Bond Portfolio Immunization and Stochastic Process Risk, "Joumal of Bank Research (Winter 1983), pp. 282-91.

Booth, James R., Fichard L. Smith, and Richard W. Stolz. "Use of Interest Rate Futures by Financial Institutions," Journal of Bank Fesearch (Spring 1984), pp. 15-20.

Cicchetti, Paul, Charles Dale and Anthony J. Vignola. "Usefuiness of Treasury Bill Futures as Hedging instruments:" Joumal of Futures Markets (Fall 1981), pp. $379-87$.

Drabenstott. Mark, and Anne OMara McDonley. "Futures Mar. kets: A Primer for Financial Institutions." Federal Reserve Bank of Kansas City Economic Review (November 1984), pp. 17-33.

Ederington, Louis $\mathrm{H}$. "The Hedging Performance of the New Futures Markets," Journal of Finance (March 1979), pp. 157-70.

Federal Home Loan Bank Board. "Interest-Pate-Risk Management; Policy Statement and Final Rule," Federal Register (Vol. 49 , No. 129 , July 3,1984 )

Franckle, Chatles T. "The Hedging Pertormance of the New Futures Markets: Comment." Joumal of Finance (December 1980), pp. $1273-79$.

Franckle, Charles T., and Andrew J. Senchack, Jr. "Economic Considerations in the Use of Interest Rate Futures," Journal of Futures Markets (Spring 1982), pp. 107-16.

Hicks, J. R. Value and Capital (Oxford: Clarendon Press, 1939)

Hill, Joanne, Joseph Liro, and Thomas Schneeweis. "Hedging Performance of GNMA Futures Under Rising and Falling Interest Rates," Journal of Futures Markets (Winter 1983), pp. 403-13.

Jacobs, Rodney L. "Restructuring the Maturity of Regulated Deposits with Treasury-Bill Futures," Journal of Futures Markets (Summer 1982), pp. 183-93.

Kane, Edward J. "Market Incompleteness and Divergences Beween Forward and Futures Interest Rates," Joumal of Finance (May 1980), pp. 221-34.

Kautman, George G. "Measuring and Managing Interest Rate Risk: A Primer," Federal Reserve Bank of Chicago Economio Perspectives (January-February 1984), pp. 16-29.

Koch, Donald L., Delores W. Steinhauser and Pamela Whigham "Financial Futures as a Risk Management Tool for Banks and S\&Ls." Federal Reserve Bank of Atlanta Economic Review (September 1982), pp. 4-14.

Kolb, F. W. Interest Rate Futures: A Comprehensive Introduction (Robert F. Dame, Inc., 1982).

Koppenhaver, G. D. "Selective Hedging of Bank Assets with Treasury Bill Futures Contracts," Joumal of Financial Research (Summer 1984), pp. 105-19.

Parker, Jack W., and Robent T. Daigler. "Hedging Money Market CDs with Treasury-Bill Futures, "Joumal of Fufures Markets (Winter 1981), pp. $597-606$

Ptts, Mark, and Robert W. Kopprasch. "Reducing Inter-Temporal Risk in Financial Futures Hedging," Journal of Futures Markets (Spring 1984), pp. 1-13.

Samuelson. P. A. "The Effect of interest Rate Increases on the Banking System." American Economic Review (March 1944), pp. $16-27$

Santoni, G. J. " "Interest Rate Risk and the Stock Prices of Financial Institutions," this Review (August September 1984), pp. 12-20.

Stigum, Marcia, Money Market Calculations: Yjelds, Break-Evens and Arbitrage (Dow Jones-irwin, 1981) 
Toevs, Aden L. "Gap Management: Managing Interest Rate Risk in Banks and Thrifts," Federal Reserve Bank of San Francisco Economic Review (Spring 1983), pp. 20-35.
Zastow, Jeffrey. "Some Thrifts and Other Concerns Find Hedging Against Rate Changes Costly," Wall Street Joumal, November 5, 1984 .

\section{Appendix Calculating the Hedge}

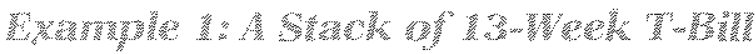

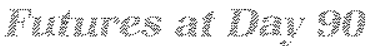

To calculate a hedge that insulates the present value of the portfolio, it is necessary to calculate the change in the present value of the portfolio for a small change in the interest rate. The estimate of interest elasticity can be used for this purpose. The interest rate is assumed to change by 5 percent $:=.005 \times 100 / .10$ in the table 1 example and interest elasticity, $n_{i}$ is estimated to be -3.811 (see panel $C$ of table 1 ). Using this estimate of interest elasticity, the change in the present value of the portfolio can be computed given the change in the interest rate. From the example in table 1 :

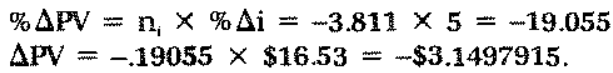

This result indicates that, if the interest rate rises by 5 percent, the present value of the portfolio will fall by about $\$ 3.15$. Notice that $\$ 3.15$ is the difference between the present value of the streams of net receipts in panels $A$ and $B$ of table 1 . This change in present value of the spot portfolio must be offset by an opposite change in the present value of the futures contract.

Using the above result, the future dollar amount, $X$, that the futures contract must generate at day 90 to offset the fall in the present value of the portfolio induced by the change in the interest rate is calculated as follows:

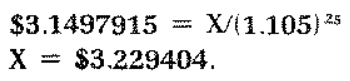

The face value of the futures contract, 5 , in 13 -week T-bills that must be sold to generate $\$ 3.229404$ for the given change in the interest rate is the difference between the amount the firm will receive upon delivery of the T-bils $\left(\mathrm{F} / 1.10^{\mathrm{T}}\right)$ and the cost of covering the contract once the interest rate has risen $\left[\mathrm{F} / 1.105^{\circ \prime \prime} \mathrm{Or}\right.$;

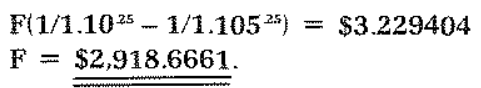

The contracted price of this futures contuct appears in fable $2|\$ 2,849.94=\$ 2,918.6661 / 1.105|$ This is the amount that the firm will receive upon delvery of the T-bills at day 90 . As long as the fimm has no expectation about the magnitude or direction of change in the interest rate, this hedge is optimal in the sense that the variance in the net present value of the portfolio is minimized for anv variation in the interest rate.

It is not necessary that the stack be placed at day 90. By slightly modifying the calculation, an optimal hedge can be obtamed for a stack of contracts on days $180,270,360,210$, etc. Even though it is possible to stack contracts on days other than the refunding dates, it still is necessary for the firm to settle the futures contracts on the refunding dates. This is required because interest ates may rise fall before the refunding date but fall trise between the refunding date and the delivery date of the futures contract.

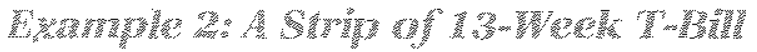

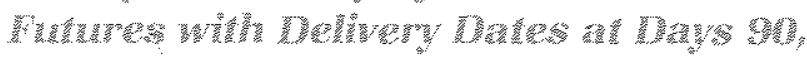

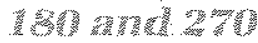

The initial procedure in this calculation is the same as in the case of the stack. In both cases, it is necessany to calculate the change in the present value of the portfolio for a small change in interest rates. For a 5 percent increase in interest rates and the portolio given in the table 1 example, this is $-\$ 3.1497915$. This change in present value must be offset by an opposite change in the present value of the futures contracts.

In the case of the strip, there are assumed to be thee contuacts of equal face value but with delivery dates at days 90,180 and 270 . The future dollar amount, $X$, that must be received on these dites so that the present value of the stream is equal to $\$ 3.1497915$ is:

$$
\begin{aligned}
& \begin{aligned}
\$ 3.1497915 & \left.=X /(1.105)^{25}+X / 1.105\right)^{50} \\
& +X /(1.105)^{75}
\end{aligned} \\
& X=\$ 1.1034477
\end{aligned}
$$

The face value of the three futures contacts, in $13-$ week T-bills that must be sold to generate $\$ 1.103447$ at days 90,180 and 270 is:

$$
\begin{aligned}
& F\left(1 / 1.10^{23}-1 / 1.105^{25}\right)=\$ 1.103447 . \\
& F=\$ 997.27175 .
\end{aligned}
$$

